\title{
Electricigens in the anode of microbial fuel cells: pure cultures versus mixed communities
}

\author{
Yujin Cao ${ }^{1 *}\left(\mathbb{D}\right.$, Hui Mu², Wei Liu', Rubing Zhang ${ }^{1}$, Jing Guo ${ }^{1}$, Mo Xian ${ }^{1 *}$ and Huizhou Liư ${ }^{1 *}$
}

\begin{abstract}
Microbial fuel cell (MFC) is an environmentally friendly technology for electricity harvesting from a variety of substrates. Microorganisms used as catalysts in the anodic chamber, which are termed as electricigens, play a major role in the operation of MFCs. This review provides an introduction to the currently identified electricigens on their taxonomical groups and electricity producing abilities. The mechanism of electron transfer from electricigens to electrode is highlighted. The performances of pure culture and mixed communities are compared particularly. It has been proved that the electricity generation capacity and the ability to adapt to the complex environment of MFC systems constructed by pure microbial cultures are less than the systems constructed by miscellaneous consortia. However, pure cultures are useful to clarify the electron transfer mechanism at the microbiological level and further reduce the complexity of mixed communities. Future research trends of electricigens in MFCs should be focused on screening, domestication, modification and optimization of multi-strains to improve their electrochemical activities. Although the MFC techniques have been greatly advanced during the past few years, the present state of this technology still requires to be combined with other processes for cost reduction.
\end{abstract}

Keywords: Microbial fuel cell, Electricigens, Pure cultures, Mixed communities

\section{Introduction}

The world's limited supply of fossil fuels and the impact of fossil fuels on climate change require us to develop alternative energy sources. Among the next generation energy sources, microbial fuel cell (MFC) is attracting wide attention due to its intended use to recover energy in the form of electricity. MFCs are fuel cells that convert chemical or solar energy to electrical energy using microorganisms as the catalysts [1]. Unlike other fuel cells, MFCs do not use precious metal catalysts at the anode [2]. Therefore, MFC technology represents a new and promising approach to generate power in an inexpensive way.

The concept of electric current generation by microorganisms has been conceived for more than 100 years and MFC devices for electricity production have been under

\footnotetext{
*Correspondence: caoyj@qibebt.ac.cn; xianmo@qibebt.ac.cn; liuhuizhou@qibebt.ac.cn

${ }^{1}$ CAS Key Laboratory of Biobased Materials, Qingdao Institute of Bioenergy and Bioprocess Technology, Chinese Academy of Sciences, Qingdao 266101, China

Full list of author information is available at the end of the article
}

intense study for about 50 years [3]. MFCs are similar to any other battery or fuel cell, consisting of two electrodes, an anode and a cathode, which are separated by the electrolytes. The difference is that they use organic compounds as substrates to generate electricity. On the anode, microorganisms oxidize organic compounds to release electrons and protons. The electrons produced during oxidation flow to the cathode through external electric circuit to produce current. In the cathode, electron acceptors react with electrons and protons to produce reduced compounds. The reduction of oxygen is the most common cathodic reaction.

Microorganisms that oxidize organic compounds and transfer electrons to the anodes of MFCs are called electricigens. The term 'electricigen' is coined to make a clear distinction in the mechanisms of power generation in MFCs. Electricity generated by electricigens is quite different from other microorganisms. In an MFC system, the electricigen used in the anodic chamber is one of the core factors affecting electricity generation performance. Here, we summarize recent development and advances of the electricigens in the anode. The electron transfer 
mechanism from the electricigens to the anode is discussed in detail. The performances of pure cultures and mixed communities are compared particularly. Future directions of electricigens in MFCs are also proposed.

\section{Mechanisms for electron transfer from electricigens to electrodes}

Electron transfer from the respiration chain of electricigens to the electrode is crucial for MFC technology in harvesting bioenergy. The process of electron transfer by microorganisms is not a natural phenomenon. Although the mechanism is as yet not completely elucidated, multiple pathways for the electron transfer from electricigens to electrodes have been proposed. Generally, these mechanisms can be divided into two types: direct electron transfer (direct contact between the cell surface and the electrode) and indirect electron transfer (through the so-called electron mediators) (Fig. 1).

For direct electron transfer, electrons should reach the outer membrane of the cell and physical contact between the outer membrane and the anode is required. Electricigens form biofilms or electrically conductive nanowires (pili and flagella) on the anode surface [4]. Electron transfer takes place through the outer membrane cytochrome and nanowires or trans-membrane electron transport proteins by direct contact without any diffusional electron mediators. The nanowires are connected to

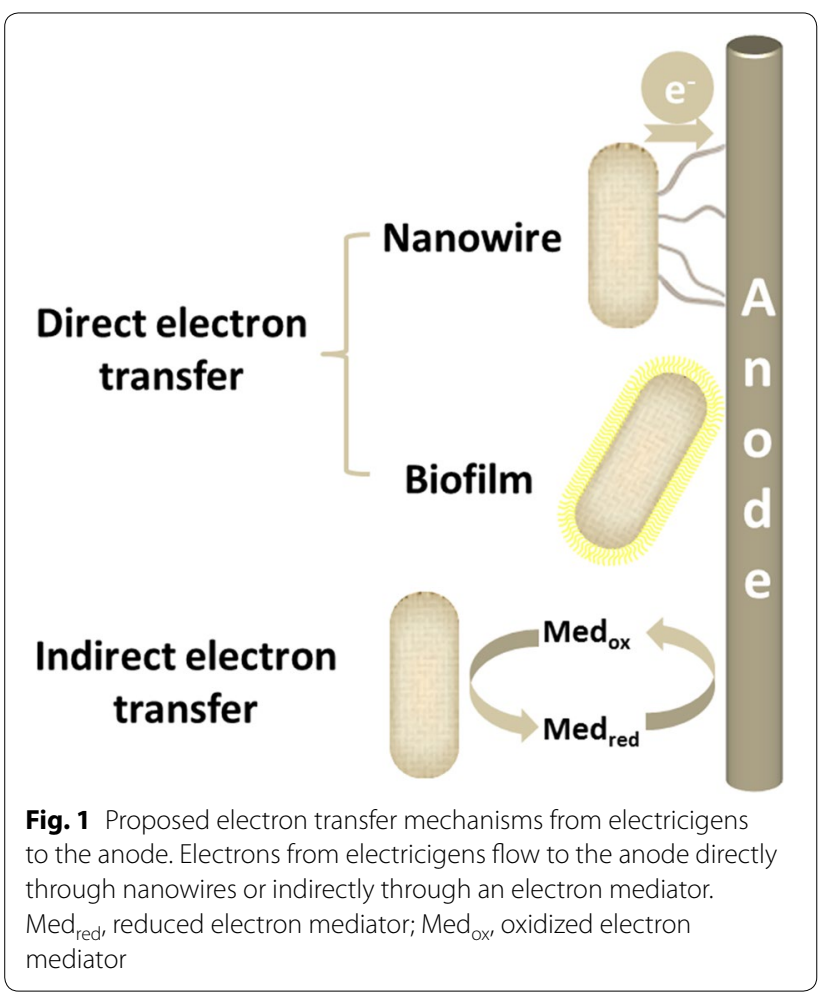

membrane bound cytochromes and allow electricigens to use an electrode which is not in direct cell contact as the electron acceptor. Electron transport proteins play an important role in direct electron transfer as they transfer electrons from the cytoplasm to the outer membrane and finally to the anode. Direct electron transfer is the first choice for efficient current generation in MFCs. The limitation of direct electron transfer is that the active sites of electron transport proteins are typically buried within the proteins, which results in poor electron transfer rate [5]. Up to now, only several species of electrochemically active bacteria such as Shewanella and Geobacter have been identified to form bacterial nanowires that transfer electrons away from the cell $[6,7]$.

For indirect electron transfer, electron transfer is achieved with the help of low molecule, soluble mediators (Fig. 2) that eliminate the requirement for direct contact between the cell and electron acceptor. The electron mediators could enter the bacteria cells, extract the electrons from the metabolic reactions of the electricigens and supply these electrons to the anode of an MFC [8]. At first, the presence of electron mediators was considered to be essential for MFC operation [9]. They can be produced by the electricigens or externally added to the anodic chamber. Many species have been identified to synthesize self-mediators such as phenazine [10, 11], pyocyanin [12], and so on. The potential difference between the mediators and the redox proteins would significantly affect the efficiency of electron transfer [13]. A number of chemical compounds like anthracenedione, thionine [14], neutral red [15], humic acid [16], riboflavin [17] and methylene blue [18] have been investigated to improve the efficiency of electron transfer. However, the addition of exogenous mediators is not preferable as they always lead to relatively low current densities as well as being expensive and toxic to the microorganisms, thus causing decline of the performance during long time periods, which makes the technique difficult to commercialize. Moreover, the regular addition of exogenous mediators is technologically unfeasible and environmentally questionable. Hence, if the microorganism can be efficiently used as a catalyst without adding exogenous mediators, it is feasible from a technical point of view that there is no need to gradually add electron mediators as well as being environmentally safe.

\section{Pure cultured microorganisms as electricigens in the anode}

As the biocatalyst of MFCs, electricigens are indispensable. Up to now, hundreds of electricigens have been isolated and used in MFCs. Most of these electricigens belong to Proteobacteria and Firmicutes. Recent studies showed that the electricigens in MFCs had a diverse 
<smiles>c1ccc2nc3ccccc3nc2c1</smiles>

Phenazine<smiles>O=C1c2ccc(S(=O)(=O)O)cc2C(=O)c2ccc(S(=O)(=O)O)cc21</smiles>

9,10-Anthraquinone-2,7-disulphonic acid<smiles>C[n+]1c2ccccc2nc2c([O-])cccc21</smiles>

Pyocyanin

\section{Self-mediators}<smiles>O=C1c2ccccc2C(=O)c2ccccc21</smiles>

9,10-Anthracenedione<smiles>O=C1OC2C=CC1C2(C(=O)O)[N+](=O)[O-]</smiles>

Humic acid<smiles>Nc1ccc2nc3ccc(N)cc3[s+]c2c1</smiles>

Thionine<smiles>Cc1cc2nc3c(=O)[nH]c(=O)nc-3n(C[C@H](O)[C@H](O)[C@H](O)CO)c2cc1C</smiles>

Riboflavin<smiles>Cc1cc2nc3ccc(N(C)C)cc3nc2cc1N</smiles>

Neutral red

\section{Exogenous mediators}

Fig. 2 Self-mediators produced by electricigens and exogenous mediators used for indirect electron transfer in MFCs

tendency. Microorganisms that have the characteristics to generate electricity are still waiting to be discovered. In order to further understand the diversity and similarity of electricigens, it is necessary to systematically summarize the existing electricity-producing microorganisms. A summary (Table 1) of the different strains according to the NCBI Taxonomy database that have been isolated from MFCs is given next.

\section{Archaebacteria}

Many archaea can survive in extreme environments such as high temperature and salinity which exert tremendous stress to the microorganisms. They have the potential to serve as electricigens in MFCs under special conditions. Two species of halophilic archaea, Haloferax volcanii and Natrialba magadii, were tested as electricigens in the anode of an MFC. Without any exogenous mediators, the maximum power density and current density reached $11.87 / 4.57 \mu \mathrm{W} / \mathrm{cm}^{2}$ and $49.67 / 22.03 \mu \mathrm{A} / \mathrm{cm}^{2}$ for $H$. volcanii and $N$. magadii, respectively. When neutral red was added as the electron mediator, the maximum power density was further improved for both of the archaea and this power output was much higher than Escherichia coli under the same conditions [19].

\section{Acidobacteria}

Acidobacteria are physiologically diverse acidophilic bacteria. They can be found in a variety of environments and are able to utilize a wide range of substrates. Several members of this phylum showed electrochemical activity. The iron-reducing bacteria Geothrix fermentans was able to produce electron mediators which promoted reduction reaction in the electrode. After optimization of the operation conditions, the current generation rate in the G. fermentans-based MFC could reach $0.6 \mathrm{~mA}$ and the electron recovery was $97 \%$ [20]. Two members of the genus Arcobacter, belonging to acidobacteria, were isolated from an acetate-fed MFC. They accounted for about $90 \%$ of the population in the MFC which produced a maximum power density of $296 \mathrm{~mW} / \mathrm{L}$. These strains specifically associated with the anode of MFCs and 
Table 1 Overview of MFCs constructed by pure cultures using different electricigens

\begin{tabular}{|c|c|c|c|c|c|}
\hline Type & Genus & Species & Current density & Power density & References \\
\hline \multirow[t]{2}{*}{ Archaea } & Haloferax & H. volcanii & $49.67 \mu \mathrm{A} / \mathrm{cm}^{2}$ & $11.87 \mu \mathrm{W} / \mathrm{cm}^{2}$ & [19] \\
\hline & Natrialba & N. magadii & $22.03 \mu \mathrm{A} / \mathrm{cm}^{2}$ & $4.57 \mu \mathrm{W} / \mathrm{cm}^{2}$ & {$[19]$} \\
\hline \multirow[t]{3}{*}{ Cyanobacteria } & Synechocystis & Synechocystis PCC-6803 & NR & $72.3 \mathrm{~mW} / \mathrm{m}^{2}$ & {$[22]$} \\
\hline & Spirulina & S.platensis & NR & $6.5 \mathrm{~mW} / \mathrm{m}^{2}$ & {$[23]$} \\
\hline & Nostoc & Nostoc sp. ATCC 27893 & $2300 \mathrm{~mA} / \mathrm{m}^{2}$ & $100 \mathrm{~mW} / \mathrm{m}^{2}$ & {$[24]$} \\
\hline Firmicutes & & C. beijerinckii & $1.3 \mathrm{~mA} / \mathrm{cm}^{2}$ & $79.2 \mathrm{~mW} / \mathrm{m}^{2}$ & {$[27,28]$} \\
\hline \multicolumn{6}{|l|}{ Proteobacteria } \\
\hline \multirow[t]{5}{*}{ a-Proteobacteria } & Rhodospirillum & R.rubrum & NR & $1.25 \mathrm{~W} / \mathrm{m}^{2}$ & {$[32]$} \\
\hline & Rhodobacter & R. sphaeroides & NR & 790 mW/m² & {$[33]$} \\
\hline & Rhodopseudomonas & R.palustris & $0.99 \mathrm{~mA} / \mathrm{cm}^{2}$ & $2720 \mathrm{~mW} / \mathrm{m}^{2}$ & {$[36]$} \\
\hline & Ochrobactrum & O. anthropic & $708 \mathrm{~mA} / \mathrm{m}^{2}$ & $89 \mathrm{~mW} / \mathrm{m}^{2}$ & [38] \\
\hline & Acidiphilium & A. cryptum & $N R$ & $12.7 \mathrm{~mW} / \mathrm{m}^{2}$ & [39] \\
\hline$\beta$-Proteobacteria & Rhodoferax & R. ferrireducens & $31 \mathrm{~mA} / \mathrm{m}^{2}$ & $12.9 \mathrm{~mW} / \mathrm{m}^{2}$ & {$[40,41]$} \\
\hline \multirow[t]{4}{*}{ y-Proteobacteria } & Escherichia & E. coli & NR & 1304 mW/m² & {$[44]$} \\
\hline & Shewanella & S. putrefaciens & $\mathrm{NR}$ & $1024 \mathrm{~mW} / \mathrm{m}^{2}$ & {$[47]$} \\
\hline & Shewanella & S. oneidensis & $515 \mathrm{~mA} / \mathrm{m}^{2}$ & $249 \mathrm{~mW} / \mathrm{m}^{2}$ & {$[80]$} \\
\hline & Pseudomonas & P. aeruginosa & $35 \mu \mathrm{A} / \mathrm{cm}^{2}$ & $\mathrm{NR}$ & {$[56]$} \\
\hline \multirow[t]{3}{*}{$\delta$-Proteobacteria } & Geobacter & G. sulfurreducens & $7.6 \mathrm{~A} / \mathrm{m}^{2}$ & $3.9 \mathrm{~W} / \mathrm{m}^{2}$ & {$[62]$} \\
\hline & Geobacter & G. metallireducens & $125 \mathrm{~mA} / \mathrm{m}^{2}$ & $26 \mathrm{~mW} / \mathrm{m}^{2}$ & {$[65]$} \\
\hline & Geopsychrobacter & G. electrodiphilus & $6.6 \mathrm{~mA} / \mathrm{cm}^{2}$ & NR & {$[66]$} \\
\hline \multirow[t]{3}{*}{ Yeast } & Saccharomyces & S. cerevisiae & $282.83 \mathrm{~mA} / \mathrm{m}^{2}$ & $25.51 \mathrm{~mW} / \mathrm{m}^{2}$ & {$[70]$} \\
\hline & Candida & C. melibiosica & NR & $185 \mathrm{~mW} / \mathrm{m}^{3}$ & {$[72]$} \\
\hline & Arxula & A. adeninivorans & NR & $1.03 \mathrm{~W} / \mathrm{m}^{3}$ & {$[74]$} \\
\hline \multirow[t]{3}{*}{ Eukaryotic algae } & Chlamydomonas & C. reinhardtii & NR & $12.95 \mathrm{~mW} / \mathrm{m}^{2}$ & {$[76]$} \\
\hline & Chlorella & C.pyrenoidosa & $\mathrm{NR}$ & $6030 \mathrm{~mW} / \mathrm{m}^{2}$ & {$[77]$} \\
\hline & Chlorella & Chlorella sp. UMACC 313 & $2.83 \mathrm{~mA} / \mathrm{m}^{2}$ & $0.124 \mathrm{~mW} / \mathrm{m}^{2}$ & [78] \\
\hline
\end{tabular}

NR, not reported

negative potentials ( -200 to $-300 \mathrm{mV}$ ) were obtained in their pure cultures [21].

\section{Cyanobacteria}

Cyanobacteria are photosynthetic microorganisms and environmentally friendly sources for bioenergy production. During the past few years, many studies have focused on the applications of cyanobacteria in MFCs. The bioelectrochemical systems based on cyanobacteria are called photosynthetic MFCs (PMFCs), which work with light as the power source and generate electricity through the light-driven oxidation of water (Fig. 3). Different species of cyanobacteria have been evaluated as the electricigens in PMFCs. A dual chamber PMFC was constructed using the model cyanobacteria Synechocystis PCC-6803. The power output of this PMFC was stable with a maximum power density of $72.3 \mathrm{~mW} / \mathrm{m}^{2}$ [22]. PMFC using Spirulina platensis as the biocatalyst could be operated at high open circuit voltage without externally added feedstocks. The maximum power density obtained by this PMFC reached $6.5 \mathrm{~mW} / \mathrm{m}^{2}$ [23]. A newly isolated cyanobacterium, Nostoc sp. ATCC 27893, was also applied in the anode of a PMFC, which generated current and power densities of $250 \mathrm{~mA} / \mathrm{m}^{2}$ and $35 \mathrm{~mW} /$ $\mathrm{m}^{2}$. When 1,4-benzoquinone was added as the electron mediator, a significant improvement in power generation ability was observed (maximum current density of $2300 \mathrm{~mA} / \mathrm{m}^{2}$ and peak power density of $100 \mathrm{~mW} / \mathrm{m}^{2}$ ) [24]. Synechococcus elongatus was used as the electricigen to study the response caused by electricity generation. The photosynthetic parameters were determined to clarify the increases of current density. However, electricity generation efficiency of the PMFC was still very low [25].

\section{Firmicutes}

Firmicutes have thick cell walls and are tolerant to harsh conditions. They could be always isolated from mixed cultures in the anode of MFCs. However, electrons need to pass through the cell wall to the anode and thus firmicutes show relatively lower electrochemical activity. Clostridium butyricum is a successful isolate 


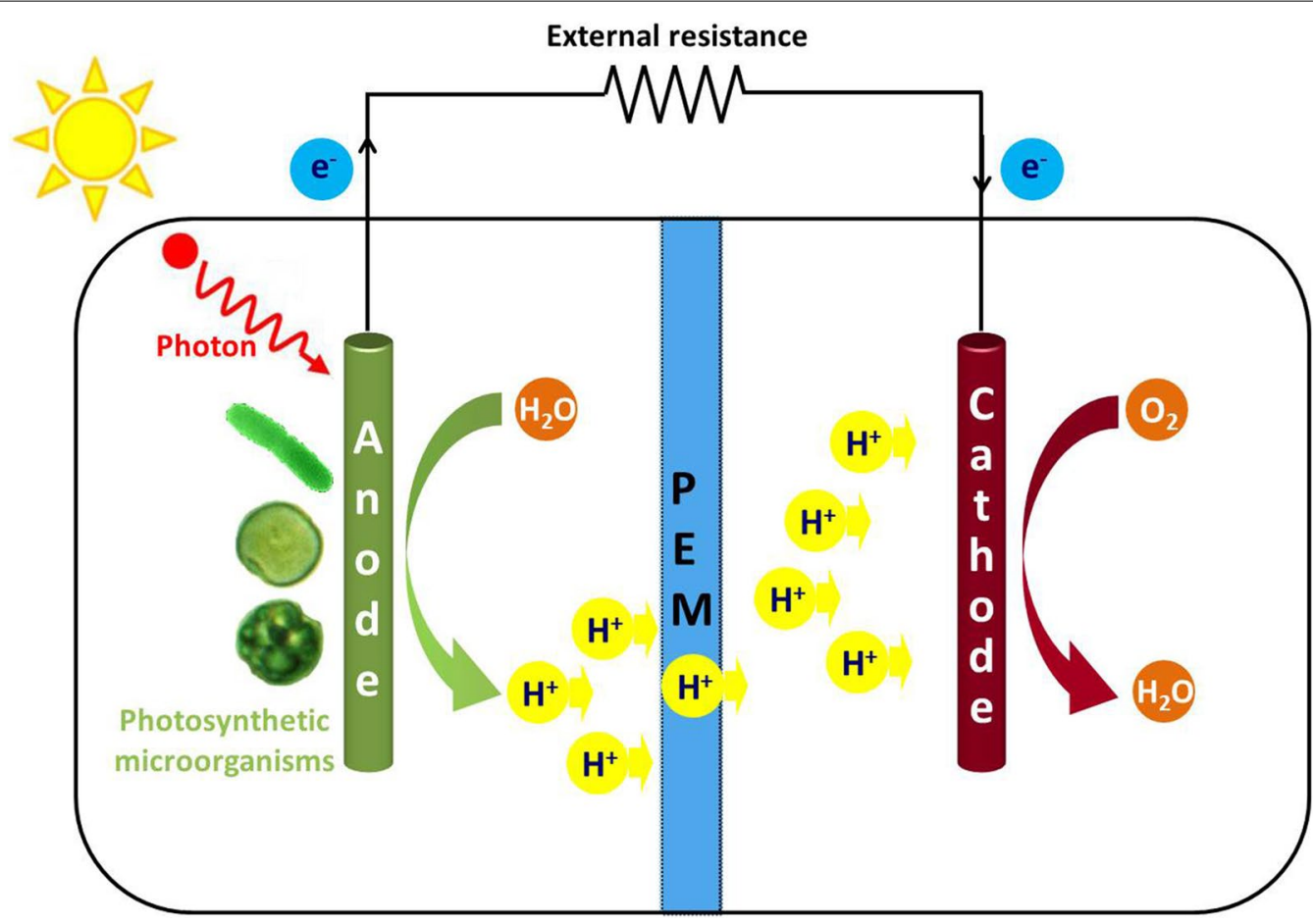

Fig. 3 The schematic diagram of a dual chamber PMFC with photosynthetic microorganisms acting as the electricigens in the anodic chamber. PEM, proton exchange membrane

of firmicutes which has be applied in MFCs. This strict anaerobe can grow at a wide $\mathrm{pH}$ and temperature range. The highest current of $0.22 \mathrm{~mA}$ was produced $10 \mathrm{~h}$ after inoculation and decreased rapidly when entering the logarithmic growth phase [26]. C. beijerinckii from the same genus could also generate electricity with a current density of $1-1.3 \mathrm{~mA} / \mathrm{cm}^{2}$ from inexpensive substrates, such as starch and molasses [27]. Mutagenesis of C. beijerinckii was further performed and the best mutant produced a maximum power density of $79.2 \mathrm{~mW} / \mathrm{m}^{2}$ in an MFC using glucose as the carbon source and methylviologen as the electron mediator [28]. The firmicute Thermincola sp. strain JR was isolated from a thermophilic MFC and demonstrated to be the dominant strain of the electricigens' community. It generated an average current of $0.42 \mathrm{~mA}$ with acetate as the substrate, accounting for approximately $70 \%$ of the electricity produced by the entire community [29]. In a methanol-fed MFC, a new strain of firmicutes was isolated and identified to be Methylomusa anaerophila by $16 \mathrm{~S}$ rRNA gene phylogenetic analysis [30].

\section{Proteobacteria}

Proteobacteria represent the largest class of electricigens which are the dominant strains in the microbial communities of MFCs. Many of them have the ability to directly transfer electrons to the electrode. In the proteobacteria phylum, electricigens are widely distributed in $\alpha$-proteobacteria, $\beta$-proteobacteria, $\gamma$-proteobacteria and $\delta$-proteobacteria.

\section{a-Proteobacteria}

Several species of $\alpha$-proteobacteria are phototrophic bacteria. Therefore, they could also be applied in PMFCs. Rhodospirillum rubrum was the first strain used to construct PMFC [31]. The dual chamber PMFC of this bacterium could produce a maximum power density of $1.25 \mathrm{~W} / \mathrm{m}^{2}$ [32]. Members of the genus Rhodobacter are good biocatalysts for PMFCs. Among them, $R$. sphaeroides is the most efficient one. In a single chamber PMFC, the power output reached $790 \mathrm{~mW} / \mathrm{m}^{2}$ [33]. The current generation ability of $R$. sphaeroides was further enhanced by genetic modification. Two mutant strains, HPC and SDH, were able to produce a current density $50 \%$ higher than the wild-type strain [34]. The performance of $R$. capsulatus in PMFCs was also explored but the current density was much lower [35]. Rhodopseudomonas can be used for biohydrogen production and they also have the potential to generate electricity. When $R$. palustris was used as the anodic biocatalyst in an MFC, a high power density of $2720 \mathrm{~mW} / \mathrm{m}^{2}$ was observed [36]. Knockout of the nitrogenase of $R$. palustris further 
improved its reducing power supply and electricity generation capability. The power density of the mutant was increased from $11.7 \mu \mathrm{W} / \mathrm{cm}^{-2}$ to $18.3 \mu \mathrm{W} / \mathrm{cm}^{-2}$ [37]. Another $\alpha$-proteobacteria, Ochrobactrum anthropi, was isolated from a special U-tube-shaped MFC. The pure culture of this strain could produce $89 \mathrm{~mW} / \mathrm{m}^{2}$ electricity using acetate as the substrate [38]. Electricity production at relatively low $\mathrm{pH}$ was achieved using the acidophilic bacterium, Acidiphilium cryptum. The power output reached $12.7 \mathrm{~mW} / \mathrm{m}^{2}$ with the help of the electron mediators [39].

\section{$\beta$-Proteobacteria}

Rhodoferax ferrireducens is the only $\beta$-proteobacteria reported as the electricigen in an MFC. It is a facultative anaerobe that can transfer electron to $\mathrm{Fe}^{3+}$. Electron mediators were not required in an $R$. ferrireducens MFC system. In a dual chamber MFC, this bacterium produced a current density of $31 \mathrm{~mA} / \mathrm{m}^{2}$ and the coulombic efficiency reached $81 \%$ when using glucose as the substrate [40]. MFC using pure culture of $R$. ferrireducens as the anodic biocatalyst obtained a peak voltage of $0.18 \mathrm{~V}$. The maximum power density reached $12.9 \mathrm{~mW} / \mathrm{m}^{2}$ in this lab-scale MFC [41].

\section{y-Proteobacteria}

$\gamma$-Proteobacteria are the most extensively studied electricigens. When Potter et al. demonstrated that electricity could be produced by microorganisms, they used the $\gamma$-proteobacteria E. coli as the electricigen. E. coli is a well-characterized model microorganism and has many advantages e.g., clear genetic background, convenience to be genetically modified and rapid growth property with low nutrients requirements [42]. Genetic tools were employed to engineer $E$. coli to enhance its electricity generation ability. Under anaerobic conditions, the tricarboxyl acid (TCA) cycle of $E$. coli is suppressed, thus leading to low power generation efficiency. Knockout of the $\operatorname{arcA}$ gene, which encodes an inhibitor of the TCA cycle, greatly improved the performance and power output of the MFC [43]. The endogenous glycerol dehydrogenase was overexpressed in $E$. coli to construct a strain as the anodic biocatalyst. This engineered strain could synthesize electron mediators which promoted electron transfer between $E$. coli cells and the electrode. The peak power density reached $1304 \mathrm{~mW} / \mathrm{m}^{2}$ in a dual chamber MFC [44]. Disruption of the lactic acid pathway of E. coli increased the intracellular reducing power level and electrons production. These electrons were released and then transferred to the anode. A much higher power output was observed when compared to the parental strain [45].

Other important electricigens of $\gamma$-proteobacteria are Shewanella and Pseudomonas. Shewanella is widely used in MFCs because of its well-characterized electron transfer mechanisms (Fig. 4). S. putrefaciens is the first bacterial strain used to construct a mediator-free MFC. It is a facultative anaerobe capable of reducing metal ions such as iron and manganese. When Kim et al. applied this strain in an MFC, they found it could generate current using lactate as the substrate [46]. A recent study employed uniform nanoflaky nickel oxide array coating strategy to improve adhesion of bacterial cells to the electrode. The performance of the S. putrefaciens MFC was improved and a maximum power density of $1024 \mathrm{~mW} / \mathrm{m}^{2}$ was achieved [47]. The potential of other Shewanella strains as electricigens was also evaluated and $S$. oneidensis showed the best capability. Two substrains of this species, S. oneidensis DSP10 and S. oneidensis MR-1, were widely used in different MFCs [48, 49]. A mutant library of $S$. oneidensis MR-1 was constructed using the random transposon-insertion method. One mutant strain, which could generate $90 \%$ higher current density, was obtained (insertion of the $u v r Y$ gene) from the library [50]. A gene responsible for the biosynthesis of cell surface polysaccharide in S. oneidensis MR-1 was knocked out. The mutant strain showed enhanced adhesion to the anode and produced 50\% more current in an MFC [51]. The $y d e H$ gene from E. coli was heterologously expressed in $S$. oneidensis MR-1 and the biofilm formation ability of the recombinant strain was significantly improved. The MFCs constructed with this strain produced a peak power density of $167.6 \mathrm{~mW} / \mathrm{m}^{2}$, about 2.8-fold of the original strain [52]. Pseudomonas aeruginosa is the earliest reported strain capable of synthesizing electron mediators. Moreover, $P$. aeruginosa can be genetically manipulated [53]. Biosynthesis of the electron mediators in $P$. aeruginosa was enhanced by engineering the 2-heptyl-3,4-dihydroxyquinoline quorum-sensing system. A maximum current density of $0.5 \mu \mathrm{A} / \mathrm{cm}^{2}$ was achieved by the engineered strain [54]. The expression PilA (structure gene coding for protein fibers to form nanowires) from G. sulfurreducens in P. aeruginosa could yield pili, whose conductivity was comparable with native G. sulfurreducens [55]. The pilT gene encoding an ATPase could increase the number of pili when it was knocked out. The pilT mutant of $P$. aeruginosa was hyperpiliated and reached a peak current density of $35 \mu \mathrm{A} /$ $\mathrm{cm}^{2}$ [56]. The maximum power density was increased by 2.7 -fold in compared to the wild-type strain [57].

\section{$\delta$-Proteobacteria}

$\delta$-Proteobacteria include two important genera Geobacter and Geopsychrobacter, many species of which could be applied in MFCs. Geobacter has the ability to reduce $\mathrm{Fe}^{3+}$ using a variety of organic compounds as electron donors [58]. G. sulfurreducens, a Gram-negative 


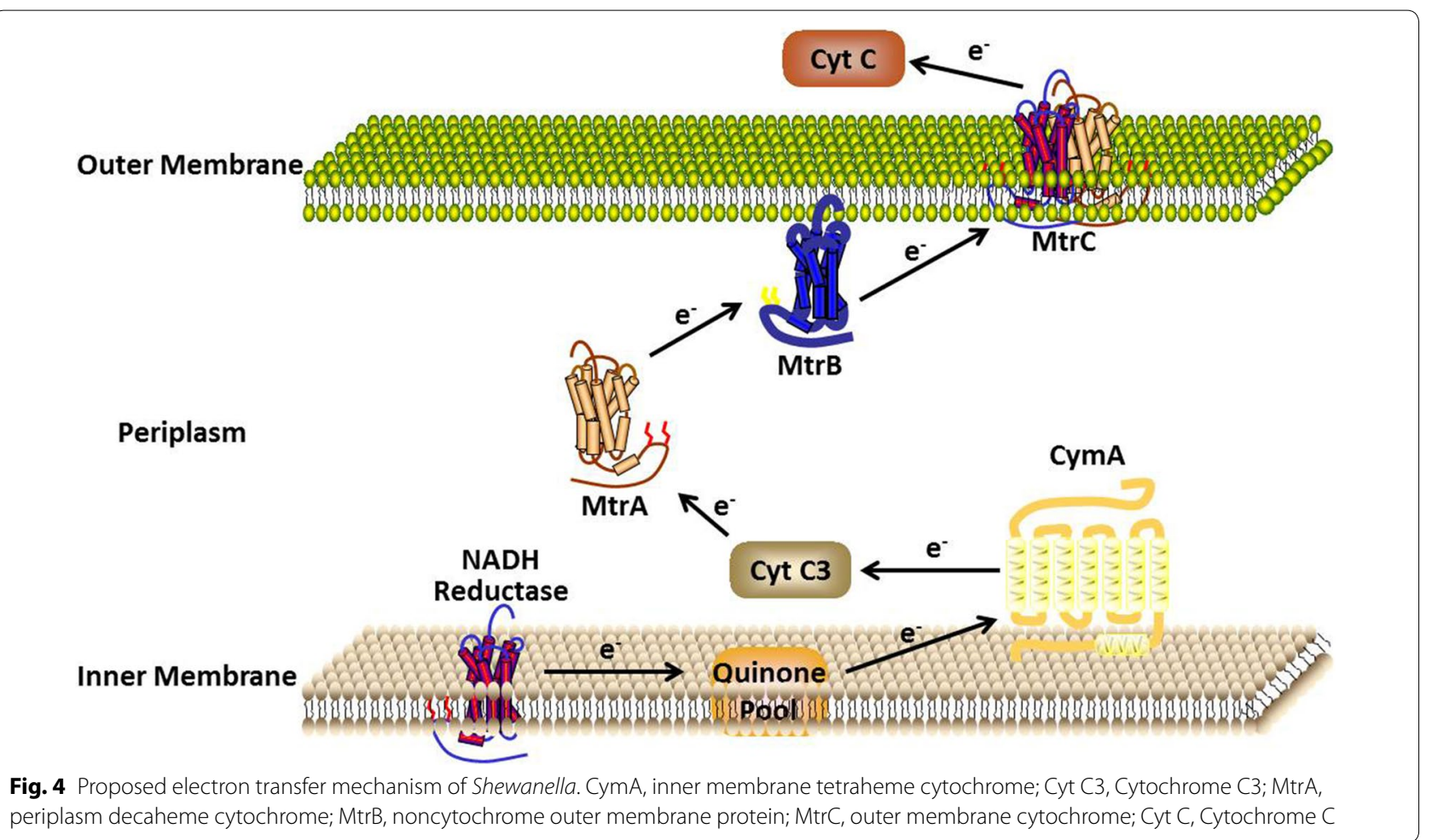

sulphur-reducing bacterium, produced the highest current among the electricigens isolated up to now. It could attach to the electrode and remain viable for a long period. When this bacterium was first investigated for its electricity generation ability, G. sulfurreducens generated electricity from acetate with an electron recovery of $96.8 \%$. The maximum power density of the MFC reached $1143 \mathrm{~mA} / \mathrm{m}^{2}$ [59]. Then the anode of the MFC was balanced by potentiostat to overcome potential electrochemical limitations and a current density as high as $2.26 \mathrm{~A} / \mathrm{m}^{2}$ was obtained [60]. Nevin et al. further demonstrated that G. sulfurreducens was capable of producing power densities comparable to mixed cultures. The maximum current density and power density reached $4.56 \mathrm{~A} / \mathrm{m}^{2}$ and $1.88 \mathrm{~W} / \mathrm{m}^{2}$, respectively. The differences in the power production between mixed communities and pure cultures were attributed to MFC design [61]. In another study, a variant of G. sulfurreducens with enhanced capacity for current production was obtained using a simple selection strategy. This mutant strain was much more effective than the wild-type strain. It generated a power output of $3.9 \mathrm{~W} / \mathrm{m}^{2}$ and a current density of $7.6 \mathrm{~A} / \mathrm{m}^{2}$ in MFC systems the same as the wild-type strain, representing five- six-fold enhancement of current generation ability [62]. G. metallireducens was also an efficient electricigen isolated from MFC devices. It comprised $90 \%$ of the anodic communities in sediment-type
MFCs operating in rice paddy fields [63]. Power output in an MFC with a pure culture of G. metallireducens reached $40 \mathrm{~mW} / \mathrm{m}^{2}$ [64]. These MFCs could be used for wastewater treatment while generating electricity. The maximum power and current densities were $26 \mathrm{~mW} /$ $\mathrm{m}^{2}$ and $125 \mathrm{~mA} / \mathrm{m}^{2}$ when using an MFC inoculated with G. metallireducens for domestic wastewater treatment [65]. Geopsychrobacter electrodiphilus was an important electricigen isolated from marine sediment MFCs. This bacterium could grow at relatively low temperature and utilize various organic substrates. A peak current density of $6.6 \mathrm{~mA} / \mathrm{cm}^{2}$ was produced from malate by the $G$. electrodiphilus based MFC with an electron recovery of $85.4 \%$ [66].

\section{Yeast}

Various bacteria have been employed as the electricigens. However, there are relatively few studies on eukaryotes as catalysts for MFCs. Yeasts are good candidates as electricigens due to their clear genetic background, fast growth rate and being generally recognized as safe [67]. In Potter's pioneering research, Saccharomyces cerevisiae was also tested for electricity generation [68]. Although yeast MFCs still produce a lower power output than bacterial MFCs, they have received renewed attention. An engineered strain of S. cerevisiae with excellent electrochemical activity was constructed by displaying glucose oxidase 
on its cell surface. The MFC showed higher power output and current density than unmodified yeast [69]. In a recent study, S. cerevisiae was used as the electricigen to evaluate electricity production and degradation of substrates under different redox conditions. Using graphite as the anode, higher current and power densities were achieved in a single chamber MFC in the absence of exogenous mediators [70]. Yeast extract was successfully applied in an S. cerevisiae MFC as the electron mediator. The addition of yeast extract can enhance the adhesion of yeast cells to the electrode. The maximum current density and power density in this dual chamber MFC reached $300 \mathrm{~mA} / \mathrm{cm}^{2}$ and $70 \mathrm{~mW} / \mathrm{cm}^{2}$, respectively [71].

Another yeast strain, Candida melibiosica, was also applied as the biocatalyst for MFCs. C. melibiosica has high phytase activity and can produce electricity without any exogenous electron mediators, which proved that this strain was an electricigen [72]. Immobilized cells of the yeast Hansenula anomala was also tested for its ability to act as the electricigen in a mediator-free MFC and efficient current generation was observed in this system. The presence of redox proteins in cell membranes was thought to contribute to direct electron transfer in the MFC [73]. The non-conventional yeast Arxula adeninivorans was another choice as an MFC catalyst. It could transfer electrons to the anode through the secretion of reducing molecules. The maximum power density in the A. adeninivorans $\mathrm{MFC}$ reached $1.03 \mathrm{~W} / \mathrm{m}^{2}$, which was one of the most effective yeast MFCs [74].

\section{Eukaryotic algae}

Algae biomass always serves as the substrates for electricigens in MFCs [75]. Moreover, algae can be used as both electron donors in the anode and acceptors in the cathode. In most cases, algae are placed at the cathode of MFCs because they can utilize $\mathrm{CO}_{2}$ to generate $\mathrm{O}_{2}$ and facilitate the cathodic reaction. Up to now, only Chlamydomonas reinhardtii and Chlorella sp. have been tested as the electricigens in the anodic chamber. The model microalga, C. reinhardtii, was investigated in PMFCs by comparing different light intensities. Red LED light allowed the PMFC to produce a higher power density $\left(12.95 \mathrm{~mW} / \mathrm{m}^{2}\right)$ than blue light. The higher the light intensity, the better the performance of the PMFC [76]. The green alga Chlorella pyrenoidosa was also introduced into the anode of a PMFC. By controlling the culture conditions, this alga could generate electricity without externally added substrates. The maximum power density was relatively as high as $6030 \mathrm{~mW} / \mathrm{m}^{2}$ [77]. A newly isolated Chlorella sp. UMACC 313 was used to form biofilms on the anode. The maximum power and current density in the PMFC reached $0.124 \mathrm{~mW} / \mathrm{m}^{2}$ and $2.83 \mathrm{~mA} / \mathrm{m}^{2}$ [78]. The algae were further immobilized in alginate gel within an MFC and the peak power output was enhanced to $0.289 \mathrm{~mW} / \mathrm{m}^{2}$ [79].

Generally, diverse of microorganisms have the potential to be used as the electricigens in MFCs. Figure 5 shows the phylogenetic analysis of typical electricigens in MFCs based on $16 \mathrm{~S}$ or $18 \mathrm{~S}$ rRNA sequences. These species could be divided into three distinct groups, the archaebacteria, the eubacteria and the eukaryotes. The eubacteria could be further classified into several subgroups according to their families and genera. There seems to be no direct correlation between the taxonomic status and their electricity-producing capability. Their electrochemical activities should be the result of convergent evolution.

\section{Mixed communities as electricigens in the anode}

The activity of at least one electricigen is the requirement for MFCs to generate electricity. However, a diversity of electricigens can also contribute to current production and, in most cases, may be more efficient. The idea of using mixed communities has thus been proposed in the last decade. Pure cultures are useful to clarify the electron transfer mechanism at the microbiological level and further reduce the specific microbial strains in mixed cultures. However, pure cultured electricigens require relatively strict operating conditions and only selective substrates can be utilized while miscellaneous consortiums are more suitable for the use of complex substrates. MFCs with the best performance are always achieved by using mixed communities, such as wastewater or activated sludge, as the anodic biocatalyst.

\section{Wastewater species}

Some species of the microorganisms in wastewater are electrochemical active. Therefore, wastewater could be directly employed as the inoculum for MFCs. Distillery wastewater contains organic substrates that can be easily degraded. It is a good source for electricity generation in MFCs. When diluted distillery wastewater was inoculated into the anode chamber, the peak power and current densities reached $168 \mathrm{~mW} / \mathrm{m}^{2}$ and $580 \mathrm{~mA} / \mathrm{m}^{2}$ [81]. Sugar beet processing wastewater was also used for electricity generation in a dual chamber MFC. Raw sugar beet processing wastewater was diluted to different concentrations and fed to the anode in batch-mode. A maximum power density of $14.9 \mathrm{~mW} / \mathrm{m}^{2}$ was obtained [82]. Brewery wastewater was used as the substrates in an MFC with special chitosan copolymer proton exchange membrane. The maximum current and power densities of this MFC were $111.94 \mathrm{~mA} / \mathrm{m}^{2}$ and $3022.39 \mathrm{~mW} / \mathrm{m}^{2}$, respectively [83]. In a recent study, industrial wastewater from different sources including chocolate industry, gum industry and slaughterhouse industry were tested as 


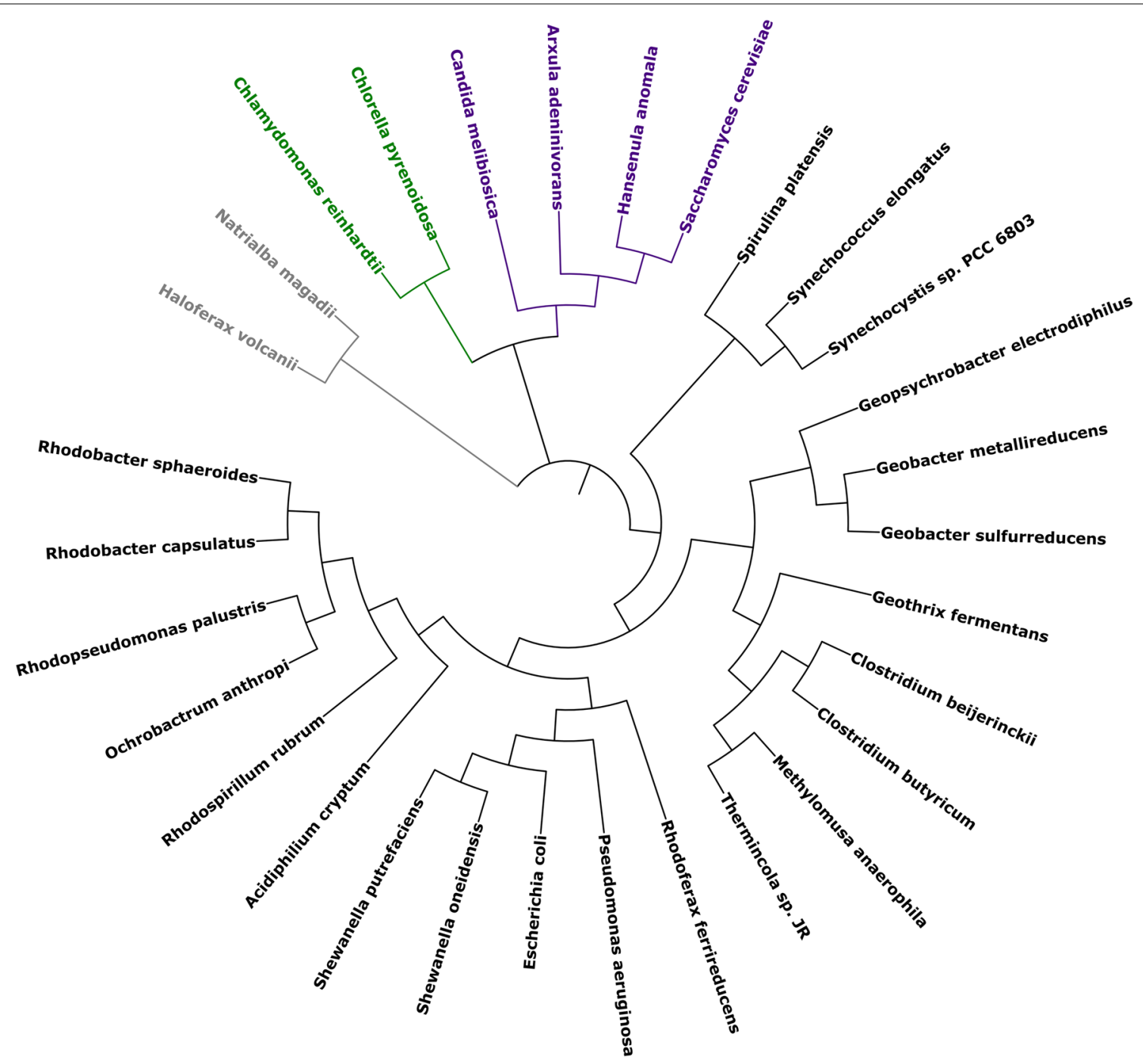

Fig. 5 Phylogenetic analysis of typical electricigens used in MFCs based on 165 or 185 rRNA sequences. Phylogenetic analysis was conducted using the MEGA7 software [1 10]. Sequence alignment was performed by ClustralW. The phylogenetic tree was constructed using the Neighbor-Joining method. GenBank accession numbers for the $16 \mathrm{~S}$ or $18 \mathrm{~S}$ rRNA sequences are: A. cryptum, NR_025851; A. adeninivorans, AB018123; C. melibiosica, AB013503; C. reinhardtii, JN863299; C. pyrenoidosa, AB240151; C. beijerinckii, LC071789; C. butyricum, AB687551; E. coli, J01859; G. metallireducens, L07834; G. sulfurreducens, NR_075009; G. electrodiphilus, NR_042768; G. fermentans, U41563; H. volcanii, NR_028203; H. anomala, NG_062034; M. anaerophila, LC203074; N. magadii, NR_028243; O. anthropic, EU275247; P. aeruginosa, NR_026078; R. capsulatus, NR_043407; R. sphaeroides, NR_029215; R. ferrireducens, NR_074760; R. palustris, M59068; R. rubrum, NR_074249; S. cerevisiae, KU350743; S. oneidensis, NR_074798; S. putrefaciens, NR_044863; S. platensis, AB074508; S. elongates, NR_074309; Synechocystis sp. PCC 6803, AY224195; Thermincola sp. JR, GU815244

the anodic catalyst. The MFC inoculated with slaughterhouse wastewater achieved the highest power density of $267 \mathrm{~mW} / \mathrm{m}^{2}[84]$.

\section{Activated sludge}

Activated sludge is a biological floc containing microbial communities as well as their dependent biodegradable organic compounds. It is also a good candidate as electricigens for MFCs [85]. Dentel et al. first demonstrated the direct generation of electricity from activated sludge.
They applied anaerobic activated sludge as the anodic inoculum and observed a power voltage of $517 \mathrm{mV}$ [86]. Activated sludge from biogas plants was used in MFCs to study the stability of the system and measure the power generated [87]. MFCs inoculated with three different types of activated sludges could simultaneously generate electricity and remove chemical oxygen demand. Heat and acid pretreatment of these sludges further improved their electricity production capacity [88]. Anaerobic sludge obtained from a wastewater treatment plant was 
used as mixed inoculums for a single-chamber MFC. The peak power density of $488 \mathrm{~mW} / \mathrm{m}^{2}$ was achieved using ethanol as the substrates [89]. Enriched activated sludge was obtained by inoculation of fly ash leachate to different media. A maximum power density of $5.43 \mathrm{~W} / \mathrm{m}^{3}$ was observed in the MFC by systematically optimizing anodic parameters [90].

The microbial populations in MFCs inoculated with wastewater or activated sludge vary greatly. To exploit the diversity of electricigens in the mixed communities, the $16 \mathrm{~S}$ rRNA gene sequencing technique was employed to analyze the microbial community structure. Phylogenetic analysis showed that electricigens in these MFCs always consisted of the strains discussed above. For instance, Tkach et al. identified 59 strains in the mixed bacterial consortia of an MFC while Geobacter and Pseudomonas were the dominant genera [91]. The microbial communities are dynamically changed during the MFC operation processes and their dynamics can be also analyzed using similar strategies. The correlation between the power density and the changes of microbial species were determined by denaturing gradient gel electrophoresis of partial 16S rRNA genes [92].

\section{Defined co-cultures}

The mixed communities in wastewater and activated sludge are very complex, making it difficult to elucidate how current is generated in such systems. Also, it is difficult to steer these mixed cultures to a stable performance. Therefore, scientists aimed to develop a defined co-culture consortium in which electricigens were rationally selected (Table 2). The co-culture system of G. sulfurreducens and E. coli was first established by $\mathrm{Qu}$ et al. The performance of this MFC was improved when compared with the pure culture of G. sulfurreducens due to the consumption of oxygen leaking into the reactor [93]. P. aeruginosa could synthesize electron mediators. Therefore, it is an excellent strain to construct co-culture systems. Defined co-cultures of $P$. aeruginosa and Enterobacter aerogenes were used as the anodic biocatalyst in an MFC. The fermentation parameters were studied to achieve higher electricity production and dissolved oxygen was identified as the key factor. After optimization of oxygen supply, $400 \%$ enhancement of current production was observed [94]. The defined co-culture system of $P$. aeruginosa and Klebsiella variicola was more efficient than either of these two strains alone, and the maximum current density was about 3 times higher [95]. Further optimization of the process parameters by response surface methodology led to a maximum power density of $12.88 \mathrm{~W} / \mathrm{m}^{3}$ [96]. Klebsiella pneumonia was another strain that could secrete electron mediators. The MFC constructed by co-culture of Klebsiella pneumonia and Lipomyces starkeyi produced a peak power density of $12.87 \mathrm{~W} / \mathrm{m}^{3}$ [97].

Co-cultured microorganisms could expand the carbon source range in MFCs. Lignocellulosic biomass is the most abundant carbohydrate in nature [98]. Since no microorganisms can simultaneously degrade biomass and transfer electrons to the electrode, the utilization of cellulosic biomass as substrates for MFCs requires a cocultured system. Ren et al. constructed an MFC inoculated with a defined co-culture of the cellulose-utilized strain Clostridium cellulolyticum and the electricigen $G$. sulfurreducens. This MFC produced peak power densities of $143 \mathrm{~mW} / \mathrm{m}^{2}$ and $59.2 \mathrm{~mW} / \mathrm{m}^{2}$ from two different kinds of cellulose, respectively [99]. S. cerevisiae and S. oneidensis co-culture consortium was rationally designed to establish a glucose-fed MFC. The co-culture conditions were systematically optimized to balance glucose catabolism and electron transfer. A maximum power density of $123.4 \mathrm{~mW} / \mathrm{m}^{2}$ was finally achieved by this MFC [100]. At present, the combination of two species did not give high gains of efficiencies as wastewater or activated sludge species. However, defined co-culture MFCs provided a strategy to study the interaction between different microorganisms in miscellaneous consortia. The interaction of G. sulfurreducens and E. coli was investigated in their

Table 2 Performance of MFCs constructed by defined co-cultured electricigens

\begin{tabular}{|c|c|c|c|c|}
\hline Species 1 & Species 2 & Current density & Power density & References \\
\hline G. sulfurreducens & E. coli & NR & $918 \mathrm{~mW} / \mathrm{m}^{2}$ & [93] \\
\hline P. aeruginosa & E. aerogenes & $212 \mu \mathrm{A} / \mathrm{cm}^{2}$ & $N R$ & [94] \\
\hline P. aeruginosa & K. variicola & $N R$ & $12.88 \mathrm{~W} / \mathrm{m}^{3}$ & [96] \\
\hline G. sulfurreducens & C. cellulolyticum & NR & $143 \mathrm{~mW} / \mathrm{m}^{2}$ & [99] \\
\hline S. oneidensis & S. cerevisiae & $369.4 \mathrm{~mA} / \mathrm{m}^{2}$ & $123.4 \mathrm{~mW} / \mathrm{m}^{2}$ & {$[100]$} \\
\hline K. pneumonia & L. starkeyi & $N R$ & $12.87 \mathrm{~W} / \mathrm{m}^{3}$ & [97] \\
\hline S. oneidensis & K. pneumonia & $10 \mathrm{~mA} / \mathrm{m}^{2}$ & $2.15 \mathrm{~mW} / \mathrm{m}^{2}$ & [102] \\
\hline S. oneidensis & E. coli & $3.0 \mu \mathrm{A} / \mathrm{cm}^{2}$ & NR & [103] \\
\hline
\end{tabular}

NR, not reported 
co-cultured MFCs. Metabonomics analysis showed that the consumption of both succinate and oxygen by $E$. coli would be helpful to increased current production by $G$. sulfurreducens [101].

\section{Conclusions and future perspectives}

The MFC technology has been greatly advanced in the past few years. However, there are not yet any practical applications of MFCs due to the limitations of their power outputs. Electricigens are the fundamental issues in the MFC systems. The application of electricigens will be the focus of future research for MFCs. To improve the performance of an MFC, it is necessary to select and breed high-quality electricigens. Recently developed metabolic engineering and synthetic biology tools have been put forward to such an extent to modify current electricigens or create novel electricigens with excellent electrochemical activities [104]. Using genetic modification, the largely unexplored potential to improve power output and electron transfer to the electrode is almost limitless. The power densities are determined not only by the electricigens but also by the architecture, electrode spacing and electrolyte conductivity of MFCs [105]. The improvements in these aspects would also contribute to enhancing the power generation efficiency of an MFC.

Moreover, MFC should be integrated with other processes to make this technique economically feasible. First, MFC can be used for wastewater treatment. Application of MFC for wastewater treatment could be an attractive alternative to reduce the cost of existing systems. The power generated by MFCs would reduce the electricity required by the wastewater treatment bioreactors [106]. Second, MFC can be used to simultaneously produce valuable products (i.e., $\mathrm{H}_{2}$ ). The protons generated in the anode could migrate to the cathode to form $\mathrm{H}_{2}$. Compared with conventional biological $\mathrm{H}_{2}$ processes, MFC can potential produce $8-9 \mathrm{~mol} \mathrm{H}_{2}$ per mol glucose instead of the theoretical yield of $4 \mathrm{~mol} \mathrm{H}_{2} /$ mol glucose [107]. Third, electricigens can sense both the presence and toxicity of chemicals. MFC-based biosensors are appropriate for real-time monitoring of environmental parameters [108]. At last, MFC for bioremediation is another promising application. MFCs have been proposed for the clean-up of various types of contamination, ranging from aromatic or substituted organic compounds to heavy metals [109]. During the bioremediation process, electricity is also generated and thus the cost is reduced. The combination of the MFC technology with other applications can make the dream of a possible large-scale launch of MFC come true.

\section{Authors' contributions}

YC drafted the initial manuscript. $H M, W L, R Z, J G, M X$ and $H L$ revised the manuscript. All authors read and approved the final manuscript.

\section{Author details}

${ }^{1}$ CAS Key Laboratory of Biobased Materials, Qingdao Institute of Bioenergy and Bioprocess Technology, Chinese Academy of Sciences, Qingdao 266101,

China. ${ }^{2}$ Shandong Key Laboratory of Biomass Gasification Technology, Energy Research Institute, Qilu University of Technology (Shandong Academy of Sciences), Jinan, China.

\section{Acknowledgements}

The authors would like to thank all the members of Biobased Materials Center for their contributions on literature collection and critical reading of the manuscript.

\section{Competing interests}

The authors declare that they have no competing interests.

Availability of data and materials

Not applicable.

Consent for publication

Not applicable.

Ethics approval and consent to participate

Not applicable.

\section{Funding}

The writing of the manuscript was sponsored by National Natural Science Foundation of China (Grant Number 31200030) and Taishan Scholars Climbing Program of Shandong (Grant Number tspd20150210).

\section{Publisher's Note}

Springer Nature remains neutral with regard to jurisdictional claims in published maps and institutional affiliations.

Received: 6 December 2018 Accepted: 12 February 2019

Published online: 19 February 2019

\section{References}

1. Allen RM, Bennetto HP. Microbial fuel-cells. Appl Biochem Biotechnol. 1993;39:27-40.

2. Logan BE. Exoelectrogenic bacteria that power microbial fuel cells. Nat Rev Microbiol. 2009; 7:375.

3. Logan BE. Introduction. In Microbial Fuel Cells. New York: Wiley; 2008. p. $1-11$.

4. Reguera G, McCarthy KD, Mehta T, Nicoll JS, Tuominen MT, Lovley DR. Extracellular electron transfer via microbial nanowires. Nature. 2005:435:1098-101.

5. Zhao F, Slade RCT, Varcoe JR. Techniques for the study and development of microbial fuel cells: an electrochemical perspective. Chem Soc Rev. 2009;38:1926-39.

6. Malvankar NS, Lovley DR. Microbial nanowires for bioenergy applications. Curr Opin Biotechnol. 2014;27:88-95.

7. Gorby YA, Yanina S, McLean JS, Rosso KM, Moyles D, Dohnalkova A, Beveridge TJ, Chang IS, Kim BH, Kim KS, et al. Electrically conductive bacterial nanowires produced by Shewanella oneidensis strain MR-1 and other microorganisms. Proc Natl Acad Sci. 2006;103:11358-63.

8. He L, Du P, Chen Y, Lu H, Cheng X, Chang B, Wang Z. Advances in microbial fuel cells for wastewater treatment. Renew Sustain Energy Rev. 2017;71:388-403.

9. Debabov VG. Electricity from microorganisms. Microbiology. 2008:77:123.

10. Peng $H$, Zhang P, Bilal M, Wang W, Hu H, Zhang X. Enhanced biosynthesis of phenazine-1-carboxamide by engineered Pseudomonas chlororaphis HT66. Microb Cell Fact. 2018;17:117.

11. Bilal M, Wang S, lqbal HMN, Zhao Y, Hu H, Wang W, Zhang X. Metabolic engineering strategies for enhanced shikimate biosynthesis: current scenario and future developments. Appl Microbiol Biotechnol. 2018;102:7759-73. 
12. Dantas PV, Peres S, Campos-Takaki GM, La Rotta CE. Utilization of raw glycerol for pyocyanin production from Pseudomonas aeruginosa in half-microbial fuel cells: evaluation of two electrochemical approaches. J Electrochem Soc. 2013;160:G142-8.

13. Evelyn L, Marshall A, Gostomski PA. Gaseous pollutant treatment and electricity generation in microbial fuel cells (MFCs) utilising redox mediators. Rev Environ Sci Bio/Technol. 2014;13:35-51.

14. Rahimnejad M, Najafpour GD, Ghoreyshi AA, Talebnia F, Premier GC, Bakeri G, Kim JR, Oh SE. Thionine increases electricity generation from microbial fuel cell using Saccharomyces cerevisiae and exoelectrogenic mixed culture. J Microbiol. 2012;50:575-80.

15. Park DH, Laivenieks M, Guettler MV, Jain MK, Zeikus JG. Microbial utilization of electrically reduced neutral red as the sole electron donor for growth and metabolite production. Appl Environ Microbiol. 1999;65:2912-7

16. Thygesen A, Poulsen FW, Min B, Angelidaki I, Thomsen AB. The effect of different substrates and humic acid on power generation in microbial fuel cell operation. Bioresour Technol. 2009;100:1186-91.

17. Zhang E, Cai Y, Luo Y, Piao Z. Riboflavin-shuttled extracellular electron transfer from Enterococcus faecalis to electrodes in microbial fuel cells. Can J Microbiol. 2014;60:753-9.

18. Rahimnejad M, Najafpour GD, Ghoreyshi AA, Shakeri M, Zare H. Methylene blue as electron promoters in microbial fuel cell. Int J Hydrogen Energy. 2011;36:13335-41.

19. Abrevaya XC, Sacco N, Mauas PJD, Cortón E. Archaea-based microbial fuel cell operating at high ionic strength conditions. Extremophiles. 2011;15:633.

20. Bond DR, Lovley DR. Evidence for involvement of an electron shuttle in electricity generation by Geothrix fermentans. Appl Environ Microbiol. 2005; $71: 2186-9$

21. Fedorovich V, Knighton MC, Pagaling E, Ward FB, Free A, Goryanin I. Novel electrochemically active bacterium phylogenetically related to Arcobacter butzleri, isolated from a microbial fuel cell. Appl Environ Microbiol. 2009;75:7326-34.

22. Ma M, Cao L, Ying X, Deng Z. Study on the performance of photosynthetic microbial fuel cells powered by Synechocystis PCC-6803. Renew Energy Resour. 2012;30:42-6.

23. Fu CC, Hung TC, Wu WT, Wen TC, Su CH. Current and voltage responses in instant photosynthetic microbial cells with Spirulina platensis. Biochem Eng J. 2010;52:175-80.

24. Sekar N, Umasankar Y, Ramasamy RP. Photocurrent generation by immobilized cyanobacteria via direct electron transport in photobioelectrochemical cells. Phys Chem Chem Phys. 2014;16:7862-71.

25. Ciniciato GPMK, Ng FL, Phang SM, Jaafar MM, Fisher AC, Yunus K Periasamy $\mathrm{V}$. Investigating the association between photosynthetic efficiency and generation of biophotoelectricity in autotrophic microbial fuel cells. Sci Rep. 2016;6:31193.

26. Park HS, Kim BH, Kim HS, Kim HJ, Kim GT, Kim M, Chang IS, Park YK, Chang $\mathrm{HI}$. A novel electrochemically active and Fe(III)-reducing bacterium phylogenetically related to Clostridium butyricum isolated from a microbial fuel cell. Anaerobe. 2001;7:297-306.

27. Niessen J, Schröder U, Scholz F. Exploiting complex carbohydrates for microbial electricity generation - a bacterial fuel cell operating on starch. Electrochem Commun. 2004;6:955-8.

28. Liu J, Guo T, Wang D, Ying H. Clostridium beijerinckii mutant obtained atmospheric pressure glow discharge generates enhanced electricity in a microbial fuel cell. Biotech Lett. 2015;37:95-100.

29. Wrighton KC, Agbo P, Warnecke F, Weber KA, Brodie EL, DeSantis TZ, Hugenholtz P, Andersen GL, Coates JD. A novel ecological role of the Firmicutes identified in thermophilic microbial fuel cells. ISME J. 2008;2:1146-56

30. Amano N, Yamamuro A, Miyahara M, Kouzuma A, Abe T, Watanabe K. Methylomusa anaerophila gen. nov., sp. nov., an anaerobic methanolutilizing bacterium isolated from a microbial fuel cell. Int J Syst Evol Microbiol. 2018;68:1118-22.

31. Berk RS, Canfield JH. Bioelectrochemical energy conversion. Appl Microbiol. 1964;12:10-2

32. Gomez MV, Mai G, Greenwood T, Mullins JP. The development and maximization of a novel photosynthetic microbial fuel cell using Rhodospirillum rubrum. J Emerg Invest. 2014;3:1-7.
33. Cho YK, Donohue TJ, Tejedor I, Anderson MA, McMahon KD, Noguera DR. Development of a solar-powered microbial fuel cell. J Appl Microbiol. 2008;104:640-50.

34. Wong MT, Cheng D, Wang R, Hsing IM. Modifying the endogenous electron fluxes of Rhodobacter sphaeroides 2.4.1 for improved electricity generation. Enzyme Microb Technol. 2016;86:45-51.

35. Hasan K, Reddy KV, Eßmann V, Górecki K, Conghaile PÓ, Schuhmann W, Leech D, Hägerhäll C, Gorton L. Electrochemical communication between electrodes and Rhodobacter capsulatus grown in different metabolic modes. Electroanalysis. 2014;27:118-27.

36. Xing D, Zuo Y, Cheng S, Regan JM, Logan BE. Electricity generation by Rhodopseudomonas palustris DX-1. Environ Sci Technol. 2008;42:4146-51.

37. Keisuke M, Makoto Y, Akihiro F, Takeyuki M, Masahiro O, Yuji F. Improving the performance of a direct photosynthetic/metabolic bio-fuel cell (DPBFC) using gene manipulated bacteria. J Micromech Microeng. 2007;17:S274-9.

38. Zuo Y, Xing D, Regan JM, Logan BE. Isolation of the exoelectrogenic bacterium Ochrobactrum anthropi YZ-1 by using a U-tube microbial fuel cell. Appl Environ Microbiol. 2008;74:3130-7.

39. Borole AP, O'Neill H, Tsouris C, Cesar S. A microbial fuel cell operating at low pH using the acidophile Acidiphilium cryptum. Biotech Lett. 2008:30:1367-72

40. Chaudhuri SK, Lovley DR. Electricity generation by direct oxidation of glucose in mediatorless microbial fuel cells. Nat Biotechnol. 2003;21:1229-32.

41. Liu ZD, Li HR. Effects of bio- and abio-factors on electricity production in a mediatorless microbial fuel cell. Biochem Eng J. 2007;36:209-14

42. Cao Y, Zhang R, Liu W, Zhao G, Niu W, Guo J, Xian M, Liu H. Manipulation of the precursor supply for high-level production of longifolene by metabolically engineered Escherichia coli. Sci Rep. 2019:9:95.

43. Liu J, Yong YC, Song H, Li CM. Activation enhancement of citric acid cycle to promote bioelectrocatalytic activity of arcA knockout Escherichia coli toward high-performance microbial fuel cell. ACS Catalysis. 2012;2:1749-52.

44. Xiang K, Qiao Y, Ching CB, Li CM. GldA overexpressing-engineered E. coli as superior electrocatalyst for microbial fuel cells. Electrochem Commun. 2009:11:1593-5.

45. Yong $Y C$, Yu YY, Yang Y, Li CM, Jiang $R$, Wang $X$, Wang JY, Song H. Increasing intracellular releasable electrons dramatically enhances bioelectricity output in microbial fuel cells. Electrochem Commun. 2012;19:13-6.

46. Kim HJ, Hyun MS, Chang IS, Kim BH. A microbial fuel cell type lactate biosensor using a metal-reducing bacterium, Shewanella putrefaciens. J Microbiol Biotechnol. 1999;9:365-7.

47. Qiao Y, Wu XS, Li CM. Interfacial electron transfer of Shewanella putrefaciens enhanced by nanoflaky nickel oxide array in microbial fuel cells. J Power Sources. 2014:266:226-31.

48. Ringeisen BR, Henderson E, Wu PK, Pietron J, Ray R, Little B, Biffinger $J C$, Jones-Meehan JM. High power density from a miniature microbial fuel cell using Shewanella oneidensis DSP10. Environ Sci Technol. 2006:40:2629-34

49. Chen G, Xu R, Liu L, Shi H, Wang G, Wang G. Limited carbon source retards inorganic arsenic release during roxarsone degradation in Shewanella oneidensis microbial fuel cells. Appl Microbiol Biotechnol. 2018;102:8093-106.

50. Kouzuma A, Oba H, Tajima N, Hashimoto K, Watanabe K. Electrochemical selection and characterization of a high current-generating Shewanella oneidensis mutant with altered cell-surface morphology and biofilm-related gene expression. BMC Microbiol. 2014;14:190.

51. Kouzuma A, Meng XY, Kimura N, Hashimoto K, Watanabe K. Disruption of the putative cell surface polysaccharide biosynthesis gene $\mathrm{SO} 3177$ in Shewanella oneidensis MR-1 enhances adhesion to electrodes and current generation in microbial fuel cells. Appl Environ Microbiol. 2010:76:4151-7.

52. Liu T, Yu YY, Deng XP, Ng CK, Cao B, Wang JY, Rice SA, Kjelleberg S, Song $H$. Enhanced Shewanella biofilm promotes bioelectricity generation. Biotechnol Bioeng. 2015;112:2051-9.

53. Chong H, Li Q. Microbial production of rhamnolipids: opportunities, challenges and strategies. Microb Cell Fact. 2017;16:137.

54. Wang VB, Chua SL, Cao B, Seviour T, Nesatyy VJ, Marsili E, Kjelleberg S, Givskov M, Tolker-Nielsen T, Song H, et al. Engineering PQS biosynthesis 
pathway for enhancement of bioelectricity production in Pseudomonas aeruginosa microbial fuel cells. PLOS ONE. 2013;8:e63129.

55. Liu X, Wang S, Xu A, Zhang L, Liu H, Ma LZ. Biological synthesis of highconductive pili in aerobic bacterium Pseudomonas aeruginosa. Appl Microbiol Biotechnol. 2018. https://doi.org/10.1007/s00253-018-9484-5.

56. Shreeram DD, Panmanee W, McDaniel CT, Daniel S, Schaefer DW, Hassett DJ. Effect of impaired twitching motility and biofilm dispersion on performance of Pseudomonas aeruginosa-powered microbial fuel cells. J Ind Microbiol Biotechnol. 2018;45:103-9.

57. Shreeram DD, Hassett DJ, Schaefer DW. Urine-powered microbial fuel cell using a hyperpiliated pilT mutant of Pseudomonas aeruginosa. I Ind Microbiol Biotechnol. 2016;43:103-7.

58. Caccavo F, Lonergan DJ, Lovley DR, Davis M, Stolz JF, McInerney MJ. Geobacter sulfurreducens sp. nov., a hydrogen- and acetate-oxidizing dissimilatory metal-reducing microorganism. Appl Environ Microbiol. 1994;60:3752-9.

59. Bond DR, Lovley DR. Electricity production by Geobacter sulfurreducens attached to electrodes. Appl Environ Microbiol. 2003;69:1548-55.

60. Reguera G, Nevin KP, Nicoll JS, Covalla SF, Woodard TL, Lovley DR. Biofilm and nanowire production leads to increased current in Geobacter sulfurreducens fuel cells. Appl Environ Microbiol. 2006;72:7345-8.

61. Nevin KP, Richter H, Covalla SF, Johnson JP, Woodard TL, Orloff AL, Jia $H$, Zhang M, Lovley DR. Power output and columbic efficiencies from biofilms of Geobacter sulfurreducens comparable to mixed community microbial fuel cells. Environ Microbiol. 2008;10:2505-14.

62. Yi H, Nevin KP, Kim BC, Franks AE, Klimes A, Tender LM, Lovley DR. Selection of a variant of Geobacter sulfurreducens with enhanced capacity for current production in microbial fuel cells. Biosens Bioelectron. 2009;24:3498-503.

63. Kouzuma A, Kasai T, Nakagawa G, Yamamuro A, Abe T, Watanabe K. Comparative metagenomics of anode-associated microbiomes developed in rice paddy-field microbial fuel cells. PLoS ONE. 2013;8:e77443.

64. Min B, Cheng S, Logan BE. Electricity generation using membrane and salt bridge microbial fuel cells. Water Res. 2005;39:1675-86.

65. Liu H, Ramnarayanan R, Logan BE. Production of electricity during wastewater treatment using a single chamber microbial fuel cell. Environ Sci Technol. 2004;38:2281-5.

66. Holmes DE, Nicoll JS, Bond DR, Lovley DR. Potential role of a novel psychrotolerant member of the family Geobacteraceae, Geopsychrobacter electrodiphilus gen. nov., sp. nov., in electricity production by a marine sediment fuel cell. Appl Environ Microbiol. 2004;70:6023-30.

67. Cao Y, Zhang H, Liu H, Liu W, Zhang R, Xian M, Liu H. Biosynthesis and production of sabinene: current state and perspectives. Appl Microbiol Biotechnol. 2018;102:1535-44.

68. Potter MC. Electrical effects accompanying the decomposition of organic compounds. Proc R Soc London Ser B. 1911;84:260-76.

69. Fishilevich S, Amir L, Fridman Y, Aharoni A, Alfonta L. Surface display of redox enzymes in microbial fuel cells. J Am Chem Soc. 2009;131:12052-3.

70. Raghavulu SV, Goud RK, Sarma PN, Mohan SV. Saccharomyces cerevisiae as anodic biocatalyst for power generation in biofuel cell: influence of redox condition and substrate load. Bioresour Technol. 2011;102:2751-7.

71. Sayed ET, Barakat NAM, Abdelkareem MA, Fouad H, Nakagawa N. Yeast extract as an effective and safe mediator for the baker's-yeast-based microbial fuel cell. Ind Eng Chem Res. 2015;54:3116-22.

72. Hubenova Y, Mitov M. Potential application of Candida melibiosica in biofuel cells. Bioelectrochemistry. 2010;78:57-61.

73. Prasad D, Arun S, Murugesan M, Padmanaban S, Satyanarayanan RS, Berchmans S, Yegnaraman V. Direct electron transfer with yeast cells and construction of a mediatorless microbial fuel cell. Biosens Bioelectron. 2007;22:2604-10

74. Haslett ND, Rawson FJ, Barriëre F, Kunze G, Pasco N, Gooneratne R, Baronian KHR. Characterisation of yeast microbial fuel cell with the yeast Arxula adeninivorans as the biocatalyst. Biosens Bioelectron. 2011:26:3742-7.

75. Kondaveeti S, Choi KS, Kakarla R, Min B. Microalgae Scenedesmus obliquus as renewable biomass feedstock for electricity generation in microbial fuel cells (MFCs). Front Environ Sci Eng. 2014;8:784-91.

76. Lan JCW, Raman K, Huang CM, Chang CM. The impact of monochromatic blue and red LED light upon performance of photo microbial fuel cells (PMFCs) using Chlamydomonas reinhardtii transformation F5 as biocatalyst. Biochem Eng J. 2013;78:39-43.

77. Xu C, Poon K, Choi MMF, Wang R. Using live algae at the anode of a microbial fuel cell to generate electricity. Environ Sci Pollut Res. 2015;22:15621-35.

78. Ng FL, Phang SM, Periasamy V, Yunus K, Fisher AC. Evaluation of algal biofilms on indium tin oxide (ITO) for use in biophotovoltaic platforms based on photosynthetic performance. PLoS ONE. 2014;9:e97643.

79. Ng FL, Phang SM, Periasamy V, Yunus K, Fisher AC. Enhancement of power output by using alginate immobilized algae in biophotovoltaic devices. Sci Rep. 2017;7:16237.

80. Lapinsonnière L, Picot M, Poriel C, Barrière F. Phenylboronic acid modified anodes promote faster biofilm adhesion and increase microbial fuel cell performances. Electroanalysis. 2013;25:601-5.

81. Naina Mohamed S, Thota Karunakaran R, Manickam M. Enhancement of bioelectricity generation from treatment of distillery wastewater using microbial fuel cell. Environ Prog Sustain Energy. 2018;37:663-8.

82. Rahman A, Borhan MS, Rahman S. Evaluation of microbial fuel cell (MFC) for bioelectricity generation and pollutants removal from sugar beet processing wastewater (SBPW). Water Sci Technol. 2017:77:387-97.

83. Harewood AJT, Popuri SR, Cadogan El, Lee CH, Wang CC. Bioelectricity generation from brewery wastewater in a microbial fuel cell using chitosan/biodegradable copolymer membrane. Int J Environ Sci Technol. 2017;14:1535-50.

84. Cetinkaya AY, Ozdemir OK, Demir A, Ozkaya B. Electricity production and characterization of high-strength industrial wastewaters in microbial fuel cell. Appl Biochem Biotechnol. 2017;182:468-81.

85. Santoro C, Flores-Cadengo C, Soavi F, Kodali M, Merino-Jimenez I, Gajda I, Greenman J, leropoulos I, Atanassov P. Ceramic microbial fuel cells stack: power generation in standard and supercapacitive mode. Sci Rep. 2018;8:3281.

86. Dentel SK, Strogen B, Chiu P. Direct generation of electricity from sludges and other liquid wastes. Water Sci Technol. 2004;50:161-8.

87. Vajda B, Bélafi-Bakó K, Nemestóthy N. Microbial fuel cells using anaerobic sludge. J Biotechnol. 2010;150:159.

88. Yadav AK, Panda P, Bag B. The performance improvement of microbial fuel cells using different waste-sludge as an inoculum. Energy Sources A. 2013;35:1828-35.

89. Kim JR, Jung SH, Regan JM, Logan BE. Electricity generation and microbial community analysis of alcohol powered microbial fuel cells. Bioresour Technol. 2007;98:2568-77.

90. Varanasi JL, Sinha P, Das D. Maximizing power generation from dark fermentation effluents in microbial fuel cell by selective enrichment of exoelectrogens and optimization of anodic operational parameters. Biotech Lett. 2017;39:721-30.

91. Tkach O, Sangeetha T, Maria S, Wang A. Performance of low temperature Microbial Fuel Cells (MFCs) catalyzed by mixed bacterial consortia. J Environ Sci. 2017:52:284-92.

92. Beecroft NJ, Zhao F, Varcoe JR, Slade RCT, Thumser AE, AvignoneRossa C. Dynamic changes in the microbial community composition in microbial fuel cells fed with sucrose. Appl Microbiol Biotechnol. 2012;93:423-37.

93. Qu Y, Feng $Y$, Wang $X$, Logan BE. Use of a coculture to enable current production by Geobacter sulfurreducens. Appl Environ Microbiol. 2012;78:3484-7.

94. Schmitz S, Rosenbaum MA. Boosting mediated electron transfer in bioelectrochemical systems with tailored defined microbial cocultures. Biotechnol Bioeng. 2018;115:2183-93.

95. Islam MA, Ethiraj B, Cheng CK, Yousuf A, Khan MMR. An insight of synergy between Pseudomonas aeruginosa and Klebsiella variicola in a microbial fuel cell. ACS Sustain Chem Eng. 2018;6:4130-7.

96. Islam MA, Ong HR, Ethiraj B, Cheng CK, Rahman Khan MM. Optimization of co-culture inoculated microbial fuel cell performance using response surface methodology. J Environ Manage. 2018;225:242-51.

97. Islam MA, Ethiraj B, Cheng CK, Yousuf A, Thiruvenkadam S, Prasad R, Rahman Khan MM. Enhanced current generation using mutualistic interaction of yeast-bacterial coculture in dual chamber microbial fuel cell. Ind Eng Chem Res. 2018;57:813-21.

98. Cao Y, Zhang R, Cheng T, Guo J, Xian M, Liu H. Imidazolium-based ionic liquids for cellulose pretreatment: recent progresses and future perspectives. Appl Microbiol Biotechnol. 2017;101:521-32. 
99. Ren Z, Ward TE, Regan JM. Electricity production from cellulose in a microbial fuel cell using a defined binary culture. Environ Sci Technol. 2007:41:4781-6.

100. Lin T, Bai X, Hu Y, Li B, Yuan YJ, Song H, Yang Y, Wang J. Synthetic Saccharomyces cerevisiae-Shewanella oneidensis consortium enables glucosefed high-performance microbial fuel cell. AIChE J. 2017;63:1830-8.

101. Bourdakos N, Marsili E, Mahadevan R. A defined co-culture of Geobacter sulfurreducens and Escherichia coli in a membrane-less microbial fuel cell. Biotechnol Bioeng. 2014:111:709-18.

102. Kim C, Song YE, Lee CR, Jeon BH, Kim JR. Glycerol-fed microbial fuel cell with a co-culture of Shewanella oneidensis MR-1 and Klebsiella pneumonae J2B. J Ind Microbiol Biotechnol. 2016:43:1397-403.

103. Wang VB, Sivakumar K, Yang L, Zhang Q, Kjelleberg S, Loo SCJ, Cao B. Metabolite-enabled mutualistic interaction between Shewanella oneidensis and Escherichia coli in a co-culture using an electrode as electron acceptor. Sci Rep. 2015;5:11222.
104. Alfonta L. Genetically engineered microbial fuel cells. Electroanalysis. 2010;22:822-31.

105. Kim BH, Chang IS, Gadd GM. Challenges in microbial fuel cell development and operation. Appl Microbiol Biotechnol. 2007;76:485.

106. Ahn Y, Logan BE. Domestic wastewater treatment using multi-electrode continuous flow MFCs with a separator electrode assembly design. Appl Microbiol Biotechnol. 2013;97:409-16.

107. Liu H, Grot S, Logan BE. Electrochemically assisted microbial production of hydrogen from acetate. Environ Sci Technol. 2005:39:4317-20.

108. Schneider G, Kovács T, Rákhely G, Czeller M. Biosensoric potential of microbial fuel cells. Appl Microbiol Biotechnol. 2016;100:7001-9.

109. Rosenbaum MA, Franks AE. Microbial catalysis in bioelectrochemical technologies: status quo, challenges and perspectives. Appl Microbiol Biotechnol. 2014:98:509-18.

110. Kumar S, Stecher G, Tamura K. MEGA7: Molecular evolutionary genetics analysis version 7.0 for bigger datasets. Mol Biol Evol. 2016;33:1870-4.
Ready to submit your research? Choose BMC and benefit from:

- fast, convenient online submission

- thorough peer review by experienced researchers in your field

- rapid publication on acceptance

- support for research data, including large and complex data types

- gold Open Access which fosters wider collaboration and increased citations

- maximum visibility for your research: over 100M website views per year

At BMC, research is always in progress.

Learn more biomedcentral.com/submissions 